\title{
SHELL TRUMPETS FROM WESTERN MEXICO
}

\section{R. Novella Institute of Archaeology}

Marine shells have been used as musical instruments in almost all parts of the world (Izikowitz 1935), including Mesoamerica, where large univalves, also called conch shells in the literature, had a utilitarian function as trumpets. Their use is well documented in most cultural areas of Mesoamerica, as in Western Mexico, through their various occurrences in archaeological contexts and museums collections. The geographical area called Western Mexico, bordering the Pacific coast and extending towards the interior, incorporates the modern states of Nayarit, Jalisco, Colima and Michoacán.

Conch shell trumpets (fig. 1) were associated with social and religious ceremonies, and were part of the priestly paraphernalia. They were used during rites of passage such as mortuary rituals in funerary ceremonies (Furst 1966, 27). In addition, conch shells were considered as funerary offerings, as in the burials and shaft tombs of Western Mexico, and as heirlooms (Kolb 1987, 102). They also had a role to play in warfare: a ceramic vessel from Western Mexico shows an individual standing at the top of a slope with a shell trumpet in his hand, while warriors stand on the slopes (von Winning 1968). Trumpets played a role in shamanistic behaviour, as in Western Mexico, and were also part of the shaman's paraphernalia: in many societies shamans may well have functioned as war leaders because of their perceived possession of spiritual power and authority in the social structure.

P. Furst believes that they were first used in ritual contexts, and only later for more secular purposes. He disagrees with Izikowitz's proposal, that the original function of the shell trumpet was that of a signal instrument, both in peace and in war (Izikowitz 1935, 229). According to Marti $(1968,67)$, however, shell trumpets might have originally been used as a means of communication, later assuming different functions within ceremonial contexts. But it is impossible to verify either of these arguments.

In Western Mexico, shell trumpets were used with or without decoration. This decoration consisted of two stages: a) by alteration of the surface of the material over the body whorl or the spire of the univalve, or both, by means of incisions, excisions, or in high relief; b) by painting. In some instances, only the second stage was performed.

The motifs illustrated on these trumpets, whose average length could vary between 17 and $22 \mathrm{~cm}$, can be divided into three categories, determined by the type of representations portrayed on the surface of the shell: anthropomorphic, zoomorphic and non-figurative. In some instances, however, two types of representations can be found on the same specimen:

1 - Anthropomorphic representations. These include representations of humans and of deities, bearing in mind that these are sometimes difficult to differentiate. Two variants, defined by stylistic characteristics, are present: a) univalves with decorated nodules, where the frontal view of a human head has been carved over the nodules of the shell (fig. $2 a$, from Colima); b) those with incised decoration, where a human head or a whole body has been incised 
on the body whorl. In fig. $2 \mathrm{~b}$, from Western Mexico, a Tlaloc representation, with his characteristic "goggle-eyes" and fanged mouth, is illustrated.

2 - Zoomorphic representations. This category embraces all the univalves with animal representations and can be divided into three variants. a) Univalves with decorated nodules, where the frontal view of an animal head, resembling that of a monkey, has been carved over four of the nodules of the univalve (fig. 2c, possibly from Michoacán). b) Those with incised decoration; in fig. 2d, from Western Mexico, the only element of decoration consists of an animal carved on the inner lip of the univalve, next to the siphonal canal. The decoration, very damaged and broken in the middle body, has been made with thin incised lines, and resembles the dorsal view of a lizard. Three dimensional lizard representations, used as symbolic and decorative elements, are a recurrent feature of Western Mexico, particularly of Colima and Jalisco. c) Univalves with painted decoration, in most instances all over the body of the shell; in fig. 2e, from Jalisco, nine double parallel zigzag lines, representing snakes, had originally been painted in white along the body whorl of the shell; five of those are still visible today, most of them incomplete.

3 - Non-figurative representations. Two variations, defined by stylistic characteristics, are found: a) the specimens with incised decoration, either made of two circles incised around each of the nodules, on the spire and on the body whorl (fig. 2f, from El Otero, Michoacán), or decorated with a border line all along the lip of the univalve, incorporating six half-circles, with a short line going though each radius (fig. $2 \mathrm{~g}$, from Ixtlán del Río, Nayarit); b) those with painted decoration (fig. $2 \mathrm{~h}$, from Jalisco), where the design, painted all over the surface, consists of a main central round-shaped motif and triangular patterns. This method of decoration, called "paint cloisonne", has been used in Mesoamerica for the decoration of pottery. Its first manifestation in Western Mexico was in the late Classic, and it seems to have spread to Central Mexico during the Postclassic (Schondube, pers. comm.)
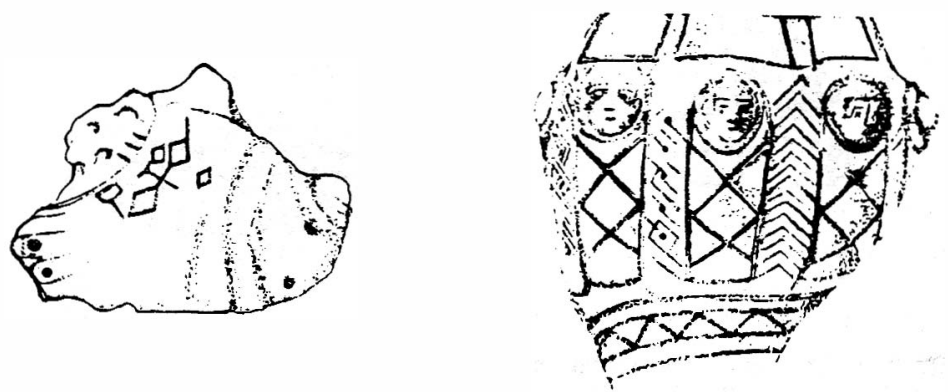

Fig. 1. Shell trumpet Museo Regional, Guadalajara, Mex.

No. FS 45.V44C

Fig. 2a. Anthropomophic representations. Mus. Cultural Hist. UCLA, USA. No. 81.00239. 


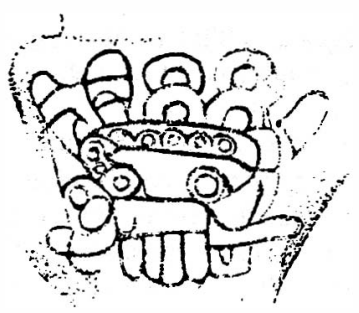

Fig. 2b. Anthropomorphic representation. Mus..Reg., Guadalajara, Mex.

No. FS 45.V44C

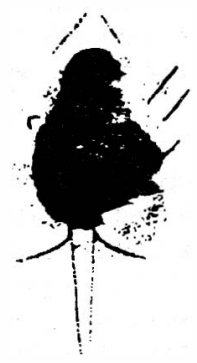

Fig. 2d. Zoomorphic representations Mus. Univ. Autónoma, Guadalajara, Mex. No. UAG.10148

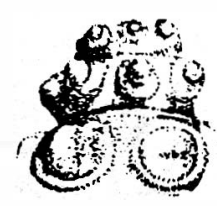

Fig. 2f. Non-figurative representations Centro de Estudio de la Revolución Mexicana, Jiquilpan, Mex. No. 39. PJ.194.
Fig.2c. Zoomorphic representation . Mus. Nac. Michoacano, Morelia, c. No. 10.83765 .

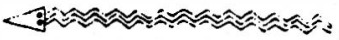

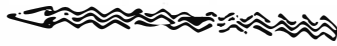 \\ -

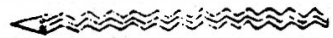

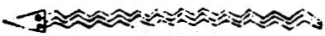

Fig. 2e. : Zoomorphic representations. Mus. für Völkerkunde, Berlin., Ger. No. IV Ca.46860

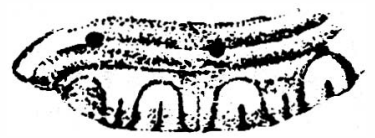

Fig. 2g. Non figurative representations. Mus. Reg. Tepic, Mex.

No. C.906.10/97366 


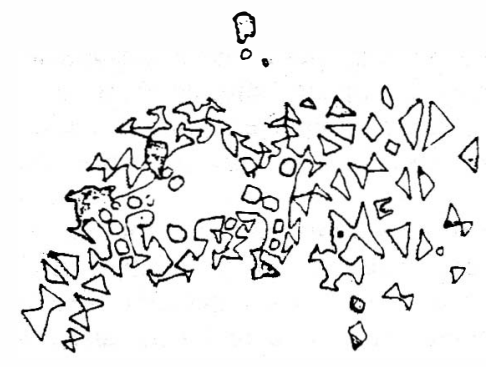

Fig. 2h Non-figurative representation. Rijksmuseum voor Völkerkunde, Leiden, Holland. No. 4541.2

Evidence provided by several shell trumpets found in archaeological contexts suggests that most specimens were painted. The painting could be applied to a surface which had been previously altered: in Las Cebollas, Nayarit, one shell bears traces of green and yellow fresco paint in combination with an incised pattern (Furst 1966, 95). And in Zuruamato, Michoacán, a residue of green stucco can be seen over the incised pattern (Irwin \& von Winning 1974). It could alternatively have been applied to an unaltered surface: in San Sebastian, Jalisco, four specimens with no other signs of decoration retain traces of yellow-brown coating (Long 1966, 217 19). When the painting covers the whole surface of the shell (figs. $2 e$ and $2 \mathrm{~h}$ ), it is difficult to determine whether this masks earlier alterations.

The techniques of painting differed according to cultural area and period. It seems that in Western Mexico the technique of "cloisonné" was often used, as seen in fig. $2 \mathrm{~h}$, and in a shell trumpet with the spiral removed, possibly from the Chapala area, decorated with a geometric pattern made of squares covering the whole surface, painted in orange, black and white (Museo Regional de Guadalajara. No. FS8.02830). The same technique of decoration is found in Casas Grandes, where a circle of "cloisonné" has been painted on one specimen (Di Peso 1974,515).

The decoration might have been symbolically associated with the use (trumpet) and meaning (ritual) of the univalve, e.g. fig. 2b. Unfortunately, it is often difficult to associate the decoration of a trumpet with any specific deity or symbolic element. However, as indicated above, direct associations with Tlaloc, with the snake and with the lizard have been found in Western Mexico. The interpretation of the last element still remains unresolved.

The source of the raw material for these instruments came from the Pacific and the Atlantic faunal provinces. The species used for their manufacture belong to four main families of gastropods, or univalves: the Fasciolariidae family, the Strombidae family, the Turbinellidae family and the Muricidae family. Some species, however, have had a wider usage and distribution in Western Mexico than others, such as the Fasciolaria princeps, the Strombus gigas and the Turbinella angulatus. In inland sites, this can be explained by the availability of the raw material, as a result of trade contacts, probably indirectly with the Atlantic coast. But in coastal sites such as Comalá, Las Hadas and Barra de Navidad, the presence of Atlantic species, 
where local ones were available, can only be explained by the preference for certain well defined shapes, such as that of the $T$. angulatus or the $S$. gigas. In addition, the religious significance attributed to these species, as well as the prestige attributed to "foreign" imported goods, could have defined the preference for certain species. This, in turn, probably created a demand for such commodities.

Why, then, were some species not used for the manufacture of shell trumpets, when they were probably fairly easily available on the nearby coasts? There seems to have been a preference for a rather limited range of species. These same species were also used for the manufacture of other shell artifacts, such as anthropomorphic and zoomorphic figurines, and other components of necklaces, and finger-loops for atlatls .

In Western Mexico, all the shell trumpets found in an archaeological context come from burials. In four instances, San Marcos, San Sebastian, El Otero and Las Cebollas, they have been found in shaft tombs. Most of the specimens included in the current research on which this present paper is based, however, have been located in museums and private collections, and their exact provenance is unknown.

The univalves were deposited in tombs with the dead as part of the ritual inventory (Porter Weaver 1981, 123), together with many other categories of mortuary offerings. Their relationship with the deceased and with the other offerings remains however unknown. The placement of objects within the burial was clearly premeditated, although the symbolic meaning behind the artifacts, including their arrangement, is still undeciphered. In San Sebastian, Tomb I, for instance, two shell trumpets were found in the same chamber next to two male skeletons (Nos. 1 and 5), in association with male ceramic figurines and an atlatl. There was probably a time gap of about 200 hundred years between both interments (Long 1966, 41).

In some instances, large univalves were used as containers for depositing offerings. In Las Cebollas, forty six small tubular beads were found impacted in the soil inside one of the Turbinella trumpets (Furst 1966, 96), and two small shell rings together with two ornaments of unknown significance were found inside another specimen (ibid, 97).

Before being used as a trumpet, some modifications had to be undertaken on the shell to control the sound. The apex of the spire was removed by grinding, and the resulting orifice was usually smoothed. Conch shells become trumpets only when a blow hole is made through the apex. Its removal was a necessary step in testing for the quality of the sound, and was certainly done in the place of manufacture, or workshop. This sounding orifice formed a simple but efficient mouthpiece. The trumpet was used by blowing into this opening, so as to allow the air to pass through the columella and exit through the aperture between the main body and the lip of the univalve: a sound was then produced, which could vary in intensity either by controlling the quantity of air blown in, or by covering part of the aperture or of the apex.

The acoustics of the conch have been little studied and there is some uncertainty about their sonic characteristics (Montagu 1981, 274). A conch trumpet is a cone-shaped tube, closely coiled like a spiral. Shell trumpets are, basically, one-note instruments, producing only one uniform sound. Durán reports on the sad sound they omit $(1967, \mathrm{Ch}$. V, 67). 
There seems, however, to have been special mechanisms to vary the tone. Some of the circular holes drilled through the surface of the univalve might have been used to modify the sound, as has been suggested by Marti $(1968,70)$. This might explain the drilling of the eight small circular holes around the apex and of the two holes on the parietal wall of one specimen from the Gulf Coast (Pitt Rivers Museum. No. 1893-69-1). In addition, Di Peso $(1974,515)$ suggests that they could probably produce basic natural tones and overtones by properly tightening the lips.

Special mouthpieces are known to have been fitted through the opening of the modified spire, and could have been used for changing the sound of the instrument. According to A. Caso $(1969,160)$, they were cylindrical in shape and probably made out of wood, clay or bone. There is no evidence for the use of this device in Western Mexico, but it is illustrated in other parts of Mesoamerica, e.g. in the mural paintings and in the stone reliefs of Teotihuacán (Miller 1973, 50, figs. 24 \& 26). In the murals of the "Templo de las Mariposas", two jaguars with plumed headdresses are seen blowing decorated conch shells with rimmed, tubular mouthpieces (Bernal 1963, photo 30). In addition, some pieces have been found in situ in Teotihuacán (Marti 1968, 70).

The linking of two shells, one with a higher tone and the other with a lower one, was reported by Furst $(1965,29)$. This practice can be seen in pottery representations from Colima, for example that of a joined pair of musicians blowing into a shell trumpet (von Winning 1974, fig. 41).

However, as Feldman $(1968,166)$ points out, the removal of the tip of the apex does not always imply the use of the univalve as a trumpet. In some cases, only a very small section of the apex was removed, barely sufficient to permit the passage of air. This feature is found in a few specimens located in Las Cebollas (Furst 1966, 95). The orifice created by the removal of the tip of the apex might have been used for the inlay of another material, perhaps stones or feathers. In the "Templo de los Caracoles Emplumados", Teotihuacán, there is a façade displaying conch shell trumpets with feathers inserted in the aperture of the apex (Bernal 1963, photo 16 \& Pl. 7).

Historical accounts, ethnographic examples and pottery figurines provide the best illustrations of the use of conch shells as musical instruments. In Michoacán, shell trumpets were blown at the funeral of Tarascan princes in the sixteenth century (Seler 1901, 155, from Kidder $e t$ al. 1946, 147). There is reference in the "Relacion de Michoacán" of their use, together with that of elongated trumpets, or horns (Craine \& Reindorp 1970): one picture illustrates four musicians in paired groups, two of them blowing into shell trumpets, over the burning of the body of a Tarascan calzonci, or ruler (ibid, Pl. 13). During the same ceremony, sea shells were placed in the tomb on the bundle of blankets containing the ashes of the Tarascan ruler.

In addition, Friar Ponce $(187313,82,114,117,119)$, during his inspection trips through Western Mexico in the sixteenth century, was received in at least six towns with the music of what seems to have been shell trumpets (from Feldman 1968, 167).

We have only one illustration, among the ethnoarchaeological examples, of the use of shell trumpets in Western Mexico. Carl Lumholtz (1900 Vol. 3, Part 1, 185 \& fig. 253) gives details of the use of a species of 
Murex as a trumpet at ceremonies and feasts, e. g. the feast of raw com tamales. Once a year the Huichol bring the shell trumpet out of its hiding place in a ceremonial centre. When the special tamales have been dedicated to the gods, the indians blow the Murex trumpet to signal the deities that the sacred feast is ready. To the Huichol the markings on the Murex shell symbolize water and kemels of com, the two most important elements in their existence (ibid 152).

It is interesting to point out that the use of shell trumpets has been revived in contemporary Central Mexico by a subgroup of the 'Concheros', called the 'Mexicas'. They still make use of shell trumpets among other musical instruments used to accompany their dances (Susanna Rostas, pers. comm.).

Male figurines, especially the redware figurines from Colima, are often depicted in association with a conch shell, and are a good illustration of the way these pieces were used, and how they were carried. Three types of such figurines are apparent:

1 - Figurines holding a shell trumpet in two hands and blowing into the instrument. The musicians are either standing or sitting. Most of these figurines are monochrome and have a single-homed headdress (Nicholson $1967,91)$. Furst $(1965,34)$ associates these single-horned figurines with shamans and the ritual functions they had to assume.

2 - Seated figurines holding a shell trumpet on one crossed leg, usually the left one, and a small stick on the opposite raised arm (Piña Chan 1960, fig. 47). These univalves could have a double use as musical instruments, to get two different sounds: the tone produced by a trumpet, as explained above, and by a rasp, with incised parallel striations along the outer lip or the siphonal canal to produce a rasping sound. This is supported by archaeological evidence from Tingambato (Piña Chan 1982, fig 27d).

3 - Figurines carrying a conch shell on their back (Bell 1971, fig. 31a). These illustrate ways in which shell trumpets were carried and explain the position of the suspension holes along the lip of the univalves to insert a string. There $i s$ however no representation of figurines wearing these univalves on their chest as a pectoral.

Numerous pottery models of shell trumpets (Gallagher 1983, fig. 85) are further indication of the importance attributed to shell trumpets in Westem Mexico. These are faithful replicas of the species used for the manufacture of the shell specimens, such as the Fasciolariidae and the Strombus varieties. A number of these pieces have had their apex removed and have the same intermal construction as a natural shell. These two facts support the view that they have certainly been used as musical instruments. An X-ray photograph of a pottery trumpet, at the American Museum of Natural History, New York, shows the interior of the instrument, where the columella and the coiled walls have been naturalistically represented (Marti 1968, 78). Further evidence in support of this view is provided among the "Concheros" of Central Mexico. One of the dancers uses a pottery representation of a shell trumpet, apparently of Maya provenance, to signal ritual moments during the dances (Susanna Rostas, pers. comm.).

Most of these pieces are monochrome, made either of a red earthenware, sometimes covered with a white slip, as in the specimens from 
Colima, or a cream ware, from Jalisco. Only one decorated piece has been located, from the Valle de Atemajac, Jalisco (Museo de Arquelogía del Occidente de México, Guadalajara). It is made of black ware ('barro oxidado'), and has a smooth, shiny surface. The design consists of thin incised lines covering the body whorl, the lip, and the siphonal canal, in a pattern of semicircles and curves enclosing rectangular motifs. The latter are covered either by a red or an off-white slip, still visible on most rectangular surfaces.

We do not know how far back in time the use of conch shells as trumpets in Western Mexico goes, as we do not have any early examples. They are present in the early Classic (Cerro Encantado, San Sebastian and Las Cebollas) and can be found up to the early Postclassic (Tingambato and Ixtlán del Rio). Based on the evidence from other sites in Mesoamerica and on historical accounts, it can be assumed that they were used from the Formative up to the Conquest periods, and probably later. Furst $(1965,30)$ points out that "conch shell trumpets represented an important object of trade as the Formative period". This is backed by the fact that they were found in Formative contexts in several sites: in Dzibilchaltún and the Isla Cancún midden (Andrews 1969, 9), in the Maya area, and in San José Mogote, Oaxaca (Flannery 1976, 336).

As most of the pieces included in this research do not come from any archaeological context, their age must be determined by stylistic comparisons, not only with analogous dated specimens from other sites, but also with other specimens from other areas. These stylistic characteristics, together with the iconographic elements illustrated on the shell trumpets, should help in interpreting the cultural and trade links of Western Mexico with other cultural areas of Mesoamerica.

There is still much uncertainty about the identity of the people who used these shell trumpets in ancient Western Mexico, why they used them and in what circumstances. We know very little about their function in mortuary contexts, and why they have been found in burials accompanying the skeleton remains of the deceased. There is unfortunately little information in Western Mexico, either from historical sources or from archaeological evidence, to help answer these questions. Their social and religious significance among the West Mexican people is illustrated by the emphasis put on the sometimes elaborate decoration which characterised these pieces and by the need to make faithful pottery replicas. We can only assume that shell trumpets were prestige goods and that there was a high demand for the raw material, which sometimes reached Western Mexico, through trade or exchange, from such remote areas as the Caribbean.

\section{References}

Andrews, E. 1969. The archaeological use and distribution of mollusca in the Maya Lowlands. New Orleans: Tulane University, Middle American Research Institute, Publication 34.

Bell, B. 1971. Archaeology of Nayarit, Jalisco and Colima. Handbook of Middle American Indians, Vol.11, Part 2. New Orleans: Tulane University, R. Wanchope: 694-753. 
Bell, B. 1974. Excavations at Cerro Encantado, Jalisco. In: Bell, B. (ed). The Archaelogy of Western Mexico. Ajijic, Mexico: S.E.A.O.M:147167.

Bernal, I. 1963. Teotihuacán. Mexico: INAH.

Caso, A. 1969. El tesoro de Monte Albán. Memorias del Instituto Nacional de Antropologia e Historia, III. Mexico: INAH, SEP.

Craine, E.R. \& Reindorp, R.C. 1970. The Chronicles of Michoacán. University of Oklahoma Press.

Di Peso, C.C. 1974. Casas Grandes, a fallen trading centre of the Gran Chichimeca. Amerind Foundation Publication, Vol. 6. Flagstaff, Arizona: Northland Press.

Durán, D. 1967. Historía de las Indias de Nueva España e Islas de la Tierra Firme . Mexico D.F.: Editorial Porrua.

Feldman, L.H. 1968. Some West Mexican archaeological molluscs. Latin American Studies, II . Los Angeles: UCLA, 165-173.

Flannery, K.V. 1976. Contextual analysis of ritual paraphernalia from Formative Oaxaca. In: Flannery, K.F.(ed). The early Mesoamerican village. New-york: Academic Press, 333-345

Furst, P.T. 1965. West Mexico, the Caribbean and Northern South America. Antropologica, 14. Caracas, Venezuela.

Furst, P. T. 1966. Shaft tombs, shell trumpets and shamanism: a culture-historical approach to problems in West Mexican archaeology unpub. Ph.D. UCLA.

Gallagher, J. 1963. Companions of the dead: ceramic tomb sculpture from ancient West Mexico. UCLA: Museum of Cultural History.

Irwin, C.N. \& von Winning, H. 1974. Conch shell trumpets in Mesoamerica. In:Pre-Columbian Art of Mexico and Central America. Santa Ana, California: the Bowers Museum.

Izikowitz, K.G. 1935. Musical and other sound instruments of the South American Indians : a comparative ethnological study. Goteborg.

Keen, A.M. 1958. Sea shells from Tropical West America. Stanford, California: Stanford University Press.

Kidder, A., Jennings, J. \& Shook, E. 1946. Excavations at Kaminaljúyu, Guatemala. Camegie Institution of Washington, Publication 561.

Kolb, C. 1987. Marine shell trade and Classic Teotihuacán, Mexico. Oxford: BAR, International Series No. 364.

Long, S. V. 1966. Archaeology of the Municipio of Eztatlán, Jalisco. unpub. Ph. D. UCLA.

Long, S. V. 1967. Funerary objects from San Marcos, Jalisco. Journal de la Société des Américanistes, Vol. 56, No. 2: 521-527.

Lumholtz, C. 1900. Symbolism of the Huichol Indians. Memoirs of the American Museum of Natural History, III-I. New York, 1-228.

Marti, S. 1968. Instrumentos prehispánicos precortesianos. Mexico D.F.: INAH.

Miller, A.G. 1973. The mural paintings of Teotihuacán. Washington, D.C.: Dumbarton Oaks.

Montagu, J. 1981. The conch in prehistory: pottery, stone and natural. World Archaeology, I2: 273-279. 
Nicholson, I. 1967. Mexican and Central American Mythology. London: Paul Hamlyn.

Noguera, E. 1944. Exploraciones en Jiquilpan. Anales del Museo Michoacáno, No. 3, Secunda Epoca.

Piña Chan, R. 1960. Mesoamerica. Memorias VI. Mexico D.F: INAH

Piña Chan, R. 1982. Exploraciones arqueológicas en Tingambato, Michoacán. Mexico D.F: INAH.

Ponce, A.. 1873. Relación breve y verdadera de algunas cosas de las muchas que sucedieron al Padre Fray Alonso Ponce en las Provincias de Nueva España. 2 Vols. Madrid: Imprenta de la Viuda de Calero.

Porter Weaver, M.N. 1981. The Aztec, Maya and their predecessors. New York: Academic Press. Second edition.

Suarez Díez, L. 1989. Conchas Prehispánicas en México. Oxford: BAR, International Series No. 514.

von Winning, H. 1968. Pre-Columbian art of Mexico and Central America . New York.

von Winning, H. 1974. The shaft tomb figures of Western Mexico. Southwest Museum Papers, 24, Los Angeles. 